\title{
Apical $\mathrm{Na}^{+} / \mathrm{H}^{+}$Antiporter and Glycolysis-dependent $\mathrm{H}^{+}$-ATPase Regulate Intracellular $\mathbf{p H}$ in the Rabbit $\mathbf{S}_{\mathbf{3}}$ Proximal Tubule
}

\author{
Ira Kurtz \\ Division of Nephrology, Department of Medicine, University of California at Los Angeles \\ School of Medicine, Los Angeles, California 90024
}

\begin{abstract}
The apical transport processes responsible for proton secretion were studied in the isolated perfused rabbit $S_{3}$ proximal tubule. Intracellular $\mathrm{pH}\left(\mathrm{pH}_{\mathrm{i}}\right)$ was measured with the $\mathrm{pH}$ dye, $\mathbf{2}^{\prime}, 7^{\prime}$ bis(carboxyethyl)-5,6-carboxyfluorescein. Steady state $\mathrm{pH}_{\mathbf{i}}$ in $\mathrm{S}_{3}$ tubules in nominally $\mathrm{HCO}_{3}^{-}$-free solutions was 7.08 \pm 0.03 . Removal of $\mathrm{Na}^{+}$(lumen) caused a decrease in $\mathrm{pH}_{\mathrm{i}}$ of $0.34 \pm 0.06$ $\mathrm{pH} / \mathrm{min}$. The decrease in $\mathrm{pH}_{\mathrm{i}}$ was inhibited $62 \%$ by $1 \mathrm{mM}$ amiloride (lumen) and was unaffected by $50 \mu \mathrm{M} 4,4^{\prime}$-diisothiocyanostilbene-2,2'-disulfonic acid (lumen) and $\mathrm{Cl}^{-}$removal (lumen, bath). After a brief exposure to $20 \mathrm{mM} \mathrm{NH}_{4} \mathrm{Cl}, \mathrm{pH}_{\mathrm{i}}$ fell by $\sim 0.7$ and recovered at a rate of $0.89 \pm 0.15 \mathrm{pH} / \mathrm{min}$ in the nominal absence of $\mathrm{Na}^{+}, \mathrm{HCO}_{3}^{-}$, organic anions, and $\mathrm{SO}_{4}{ }^{2-}$ (lumen, bath). $1 \mathrm{mM} \boldsymbol{N}, \boldsymbol{N}^{\prime}$-dicyclohexylcarbodiimide (lumen), $1 \mathrm{mM} N$-ethylmaleimide (lumen), $0.5 \mathrm{mM}$ colchicine (bath), and $0.5 \mathrm{mM}$ iodoacetic acid (lumen, bath) inhibited the $\mathrm{Na}^{+}$-independent $\mathrm{pH}_{\mathrm{i}}$ recovery rate by $73 \%, 55 \%, 77 \%$, and $86 \%$, respectively, whereas $1 \mathrm{mM} \mathrm{KCN}$ (lumen, bath) did not inhibit $\mathrm{pH}_{\mathbf{i}}$ recovery. Reduction of intracellular, but not extracellular chloride, also decreased the $\mathrm{Na}^{+}$-independent $\mathrm{pH}_{\mathbf{i}}$ recovery rate. In conclusion, the $S_{3}$ proximal tubule has an apical $\mathrm{Na}^{+} / \mathrm{H}^{+}$antiporter with a Michaelis constant for $\mathrm{Na}^{+}$of 29 $\mathrm{mM}$ and a maximum velocity of $0.47 \mathrm{pH} / \mathrm{min}$. $\mathrm{S}_{3}$ tubules also possess a plasma membrane $\mathrm{H}^{+}$-ATPase that can regulate $\mathrm{pH}_{\mathrm{i}}$, has a requirement for intracellular chloride, and utilizes ATP derived primarily from glycolysis.
\end{abstract}

\section{Introduction}

The renal proximal convoluted tubule and superficial proximal straight tubule possess an apical $\mathrm{Na}^{+} / \mathrm{H}^{+}$antiporter that contributes to the absorption of luminal bicarbonate and to intracellular $\mathrm{pH}\left(\mathrm{pH}_{\mathrm{i}}\right)^{1}$ regulation (1-5). In addition to the apical $\mathrm{Na}^{+} / \mathrm{H}^{+}$antiporter, there is evidence that the proximal tubule possesses a $\mathrm{Na}^{+}$-independent $\mathrm{H}^{+}$-ATPase that may also

Address correspondence and reprint requests to Dr. I. Kurtz, Division of Nephrology, Rm. 7-155 Factor Bldg., 10833 Le Conte Blvd., Los Angeles, CA 90024.

Received for publication 3 February 1987 and in revised form 20 May 1987.

1. Abbreviations used in this paper: $\mathrm{BCECF}, 2^{\prime}, 7^{\prime}$-bis(carboxyethyl-5,6carboxyfluorescein; BCECF-AM, BCECF-acetoxymethyl ester; DCCD, $N, N^{\prime}$-dicyclohexylcarbodiimide; DIDS, 4,4'-diisothiocyanostilbene-2,2'-disulphonic acid; GTP, guanosine 5'-triphosphate; NEM, $N$-ethylmaleimide; $\mathrm{pH}_{\mathrm{i}}$, intracellular $\mathrm{pH}$.

J. Clin. Invest.

(c) The American Society for Clinical Investigation, Inc.

0021-9738/87/10/0928/08 \$2.00

Volume 80, October 1987, 928-935 function to absorb luminal bicarbonate and regulate $\mathrm{pH}_{\mathrm{i}}(6-12)$.

We have recently demonstrated that the rabbit outer medullary proximal straight tubule $\left(\mathrm{S}_{3}\right.$ segment) generates a spontaneous luminal acidic disequilibrium $\mathrm{pH}$ of -0.46 (13). This finding indicated that the $S_{3}$ segment lacks functional luminal membrane-bound carbonic anhydrase and that the luminal fluid is acidified by proton secretion. The previous study did not address the transport mechanism(s) responsible for apical proton secretion in this segment. In the present study, we utilized newly developed fluorescent methodology for monitoring $\mathrm{pH}_{\mathrm{i}}$ in isolated perfused tubules to determine directly the apical transport processes responsible for proton secretion in the rabbit $S_{3}$ proximal tubule.

\section{Methods}

Procedures. Tubules were dissected from male New Zealand white rabbits. The rabbits were killed by cervical dislocation and one kidney was removed and sliced into coronal sections. Superficial proximal straight tubules ( $S_{2}$ segment) were dissected from the superficial medullary rays. The outer medullary proximal straight tubules $\left(\mathbf{S}_{3}\right.$ segment) were dissected by locating the beginning of a descending thin limb of Henle in the outer medulla and dissecting towards the cortex. No attempt was made to distinguish between the $S_{3}$ segment of superficial and juxtamedullary nephrons. The mean lengths of the dissected segments were $0.98 \pm 0.03 \mathrm{~mm}$ for $S_{2}$ tubules and $0.94 \pm 0.01 \mathrm{~mm}$ for $S_{3}$ tubules.

The tubules were transferred to a specially designed perfusion chamber (total volume $170 \mu \mathrm{l}$ ) that was blackened to minimize scattering of the excitation and emission light by the tubule and bathing solution. The tubules were mounted on concentric glass pipets, as described (14), except that a guard pipet was not used on the perfusion or collection end. The bathing solution was preheated to $37^{\circ} \mathrm{C}$ in a water-jacketed chamber and flowed by gravity through Saran tubing into the perfusion chamber at a rate of $\sim 2 \mathrm{ml} / \mathrm{min}$. Using this system, the bathing solution was continually flowing during an experiment with minimal tubule movement and without the formation of bubbles in the perfusion chamber. The bathing solution could be completely exchanged with a different solution in $\sim 2 \mathrm{~s}$. In all experiments, the tubules were perfused rapidly at a rate of $\sim 50 \mathrm{nl} / \mathrm{min}$ per $\mathrm{ml}$. Perfusate solutions could be completely changed in $\sim 5 \mathrm{~s}$.

Fluorescent measurement of $\mathrm{pH}_{i} \cdot \mathrm{pH}_{\mathrm{i}}$ was monitored using the fluorescent probe 2',7'-bis(carboxyethyl)-5,6-carboxyfluorescein (BCECF) (15) and a microfluorometer coupled to the tubule perfusion apparatus. To load the tubule cells with dye, the tubule was exposed to $13 \mu \mathrm{M} \mathrm{BCECF}$-acetoxymethyl ester (AM) in the bathing solution for $10 \mathrm{~min}$. (BCECF-AM was stored in dimethyl sulfoxide (DMSO) as a 4-mM stock solution at $0^{\circ} \mathrm{C}$ ). After the loading period, the bath solution was replaced with an identical dye-free solution for at least $5 \mathrm{~min}$ before beginning an experiment. The tubule was not exposed to BCECF-AM in the bathing solution during an experiment since $(a)$ some of the stock solution of BCECF-AM in DMSO hydrolyzes over time, forming BCECF that will cause the solution bathing the tubule to fluoresce and interfere with the cell measurements, and $(b)$ the $\mathrm{pH}_{\mathrm{i}}$ of the tubule cells immediately after the dye-loading procedure appears to be $\sim 0.1 \mathrm{pH}$ units lower than the final steady state $\mathrm{pH}_{\mathrm{i}}$. The acidifica- 
tion of $\mathrm{pH}_{\mathrm{i}}$ by hydrolyzable esters has been previously reported, e.g., 5(6)-carboxyfluorescein diacetate (16), QUIN-2 acetoxymethyl ester (16), and 5(6)-carboxy-4',5'-dimethylfluorescein diacetate (17). ${ }^{2}$ The tubule was therefore bathed for at least $5 \mathrm{~min}$ after the loading procedure in a dye-free solution in order for $\mathrm{pH}_{\mathrm{i}}$ to recover.

The excitation spectrum of BCECF has an excitation peak at $\sim 500 \mathrm{~nm}$ and an isosbestic point at $440 \mathrm{~nm}$. The emission spectrum has a peak at $530 \mathrm{~nm}(15)$. The $500 / 440 \mathrm{~nm}$ excitation ratio monitoring the fluorescence emission at $530 \mathrm{~nm}$ corresponds to a specific $\mathrm{pH}_{\mathrm{i}}$. A microfluorometer was developed by modifying a microscope (Zeiss IM; Carl Zeiss, Inc., Thornwood, NY) to allow for the monitoring of two excitation intensities simultaneously, which prevented bleaching, dye leakage, and movement artifacts from affecting the measurement (Fig. 1). The tubule cells were excited simultaneously at $440 \mathrm{~nm}$ (bandpass filter; Ditric Optics Inc., Signal Technology Corp., Hudson, MA) using a 100-W mercury arc lamp and at $500 \mathrm{~nm}$ (bandpass filter; Ditric Optics Inc., Signal Technology Corp.) using a 75-W xenon arc lamp by combining the two beams with a dichroic mirror (Blue reflective filter; Corion Corp., Holliston, MA). The two excitation sources were attenuated with neutral density filters and were each modulated at a different frequency using a five-slot chopper (Stanford Research Systems, Inc., Palo Alto, CA) coupled to the output of each light source. An electronic shutter (Vincent Associates, Rochester, NY) in front of each arc lamp exposed the cells to the excitation light only during data acquisition to minimize bleaching and photodamage. The 530-nm fluorescence emission (bandpass filter; Ditric Optics Inc., Signal Technology Corp.) was detected with a photomultiplier tube (Thorn EMI Gencom, Inc., Fairfield, NJ) and resolved into the 440and 500-nm components using two lock-in amplifiers (Model SR510; Stanford Research Systems, Inc., Palo Alto, CA). The two fluorescent intensities and the $500 / 440 \mathrm{~nm}$ excitation ratio were recorded on a three-pen strip chart recorder (Model SR6221; Western Graphtec Inc. Irvine, CA) and digitized by a computer (model MC-560; Masscomp, Westford, MA) for analysis and storage. In all experiments, the scattered background intensity at 440 and $500 \mathrm{~nm}$ were electronically subtracted from the fluorescent intensity at these wavelengths. Data was acquired from the proximal $0.7 \mathrm{~mm}$ of the tubule using a $20 \times$ objective (Carl Zeiss, Inc.). Calibration of intracellular BCECF was performed by monitoring the $500 / 440-\mathrm{nm}$ excitation ratio at various values of $\mathrm{pH}_{\mathrm{i}} \cdot \mathrm{pH}_{\mathrm{i}}$ was set approximately equal to the extracellular $\mathrm{pH}$ by exposing the cells to a solution containing $\mathrm{KCl}, 115 \mathrm{mM} ; \mathrm{NaCl}, 20$ $\mathrm{mM} ; \mathrm{K}_{2} \mathrm{HPO}_{4}, 2.5 \mathrm{mM} ; \mathrm{CaCl}_{2}, 1 \mathrm{mM} ; \mathrm{MgCl}_{2}, 1 \mathrm{mM}$; glucose, $5 \mathrm{mM}$; alanine, $5 \mathrm{mM}$; Hepes, $5 \mathrm{mM}$; and nigericin, $13.8 \mu \mathrm{M}$ that was titrated to a given $\mathrm{pH}$. The calibration curve depicted in Fig. 2 (mean of five determinations) was used to convert all fluorescence data to $\mathrm{pH}_{\mathrm{i}}$. The in vivo calibration curve was identical in $S_{2}$ and $S_{3}$ tubules. None of the chemicals used in the present study altered the spectral properties or calibration of BCECF.

Solutions. The composition of the perfusate and bathing solutions was as follows: $\mathrm{Na}^{+}, 140 \mathrm{mM} ; \mathrm{K}^{+}, 5 \mathrm{mM} ; \mathrm{Ca}^{2+}, 1 \mathrm{mM} ; \mathrm{Mg}^{2+}, 1 \mathrm{mM}$; $\mathrm{Cl}^{-}, 144 \mathrm{mM}$; phosphate, $2.5 \mathrm{mM}$; glucose, $5 \mathrm{mM}$; alanine, $5 \mathrm{mM}$; and Hepes, $5 \mathrm{mM}$, equilibrated with $100 \% \mathrm{O}_{2}, \mathrm{pH} 7.4$. When $\mathrm{Na}^{+}$-free solutions were used, $\mathrm{NaCl}$ was replaced with tetramethylammonium chloride. In $\mathrm{Cl}^{-}$-free experiments, $\mathrm{Cl}^{-}$was replaced with equimolar gluconate and the total $\mathrm{Ca}^{2+}$ was increased to $3.5 \mathrm{mM}$ as calcium gluconate. In experiments designed to acutely lower $\mathrm{pH}_{\mathrm{i}}$ using the $\mathrm{NH}_{4} \mathrm{Cl}$ prepulse technique (18), $20 \mathrm{mM} \mathrm{NH}_{4} \mathrm{Cl}$ replaced $20 \mathrm{mM} \mathrm{NaCl}$. When sodium- and chloride-free studies were performed, tetramethylammonium gluconate replaced equimolar $\mathrm{NaCl}$, and total $\mathrm{Ca}^{2+}$ increased to $3.5 \mathrm{mM}$ as calcium gluconate. Tetramethylammonium glu-

2. Since BCECF-AM has two more esterified carboxyl groups than 5(6)-carboxyfluorescein diacetate or 5(6)-carboxy-4, $5^{\prime}$ dimethylfluorescein diacetate, it would be expected that at identical intracellular concentrations, BCECF-AM would release approximately twice as many protons upon hydrolysis. Whether this release of protons intracellularly fully accounts for the acidification of $\mathrm{pH}_{\mathrm{i}}$ is not known.

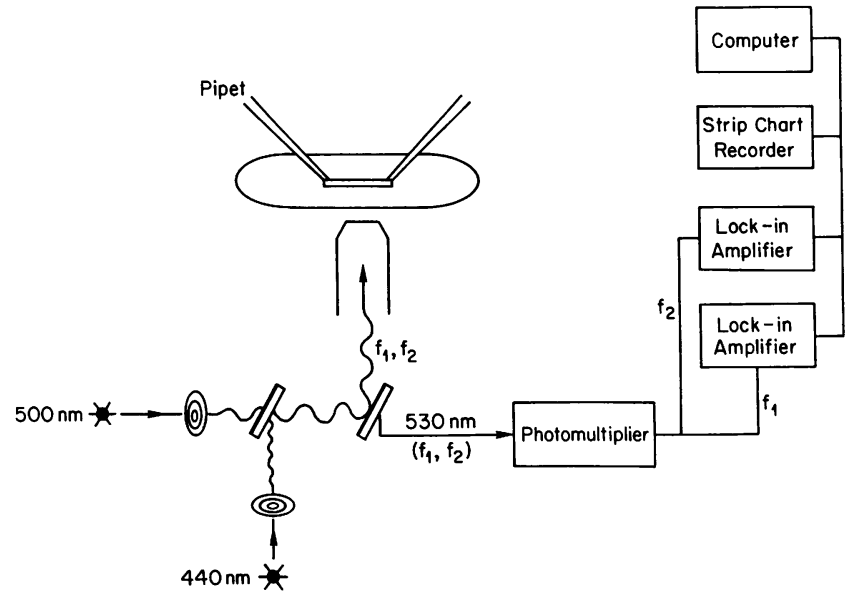

Figure 1. Microfluorometer designed to measure $\mathrm{pH}_{\mathrm{i}}$ in isolated perfused tubule cells. Tubule cells were excited simultaneously at 440 and $500 \mathrm{~nm}$ using two excitation sources each chopped at a separate frequency. The $530 \mathrm{~nm}$ fluorescence emission was detected with a photomultiplier tube and resolved into the 440 and $500 \mathrm{~nm}$ components using two lock-in amplifiers. The data was recorded on a strip chart recorder and was digitized for storage and analysis on a computer (model MC-560; Masscomp).

conate was made by reacting tetramethylammonium hydroxide with equimolar D-gluconic acid lactone. In some experiments, ammonium gluconate was made by reacting ammonium hydroxide with equimolar D-gluconic acid lactone.

Materials. 4,4'-diisothiocyanostilbene-2,2'-disulphonic acid (DIDS) (Sigma Chemical Co., St. Louis, MO). (A stock solution of $50 \mathrm{mM}$ DIDS [dissolved in DMSO] was made on the day of study and kept in the dark). BCECF-AM (Molecular Probes Inc., Junction City, OR), tetramethylammonium chloride (Sigma Chemical Co.), calcium gluconate (Sigma Chemical Co.), magnesium gluconate (Sigma Chemical Co.), sodium gluconate (Sigma Chemical Co.), amiloride hydrochloride dihydrate (Merck Sharp \& Dohme Div., West Point, PA), nigericin (Sigma Chemical Co.), iodoacetic acid (Sigma Chemical Co.), potassium cyanide (Aldrich Chemical Co., Milwaukee, WI), ATP (Sigma Chemical Co.), AMP (Sigma Chemical Co.), guanosine 5'-triphosphate (GTP) (Sigma Chemical Co.), tetramethylammonium hydroxide (Sigma Chemical Co.), colchicine (Sigma Chemical Co.), D-gluconic acid lactone (Sigma Chemical Co.), $N, N^{\prime}$-dicyclohexylcarbodiimide (DCCD) (Sigma Chemical Co.), and $N$-ethylmaleimide (NEM) (Sigma Chemical Co.) were used in this study.

Statistics. Results are reported as mean \pm SEM. Unpaired student's $t$ test was used to compare group means. Linear regression analysis was used as required.

\section{Results}

Apical $\mathrm{Na}^{+} / \mathrm{H}^{+}$antiporter. The following series of experiments were performed to examine whether the $S_{3}$ tubule possesses an

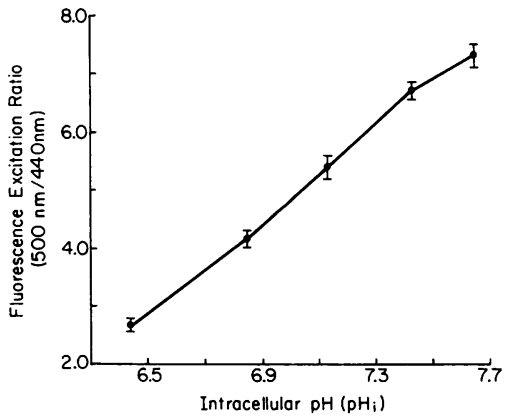

Figure 2. In vivo calibration curve of $\mathrm{BCECF}$ in $\mathrm{S}_{3}$ tubules. Each point represents the mean \pm SEM of five determinations. 
apical $\mathrm{Na}^{+} / \mathrm{H}^{+}$antiporter. Steady state $\mathrm{pH}_{\mathrm{i}}$ in tubules bathed and perfused in Hepes-buffered solutions in the absence of organic anions, $\mathrm{SO}_{4}{ }^{2-}, \mathrm{pH} 7.4$, was $7.08 \pm 0.03(n=45)$. When luminal $\mathrm{Na}^{+}$was decreased from 140 to $0 \mathrm{mM}$ (Fig. 3, Table I), $\mathrm{pH}_{\mathrm{i}}$ fell at a rate of $0.34 \pm 0.06 \mathrm{pH} / \mathrm{min}(n=9)$. Readdition of $140 \mathrm{mM} \mathrm{Na}^{+}$to the lumen resulted in the recovery of $\mathrm{pH}_{\mathrm{i}}$. In the presence of $10^{-3} \mathrm{M}$ luminal amiloride (Fig. 3, Table I), the rate of change of $\mathrm{pH}_{\mathrm{i}}$ upon luminal $\mathrm{Na}^{+}$removal was significantly decreased to $0.13 \pm 0.03 \mathrm{pH} / \mathrm{min}(n=6), P<0.05$. In the presence of $50 \mu \mathrm{M}$ luminal DIDS, the decrease in $\mathrm{pH}_{\mathrm{i}}$ upon luminal $\mathrm{Na}^{+}$removal was not different from control tubules, $0.31 \pm 0.04 \mathrm{pH} / \mathrm{min}(n=8)$, and readdition of $140 \mathrm{mM} \mathrm{Na}^{+}$to the lumen resulted in the recovery of $\mathrm{pH}_{\mathrm{i}}$ (Fig. 3, Table I). When $\mathrm{S}_{3}$ tubules were perfused and bathed in $\mathrm{Cl}^{-}$-free solutions, removal of luminal $\mathrm{Na}^{+}$resulted in a decrease in $\mathrm{pH}_{\mathrm{i}}$ of $0.32 \pm 0.05 \mathrm{pH} / \mathrm{min}(n=4)$, which was not significantly different from the control rate (Fig. 3, Table I). These results suggest that the $\mathrm{S}_{3}$ tubule possesses a luminal $\mathrm{Na}^{+} / \mathrm{H}^{+}$antiporter.

The kinetics of the apical $\mathrm{Na}^{+} / \mathrm{H}^{+}$antiporter were determined by measuring the rate of increase in $\mathrm{pH}_{\mathrm{i}}$ upon the readdition of varying concentrations of $\mathrm{Na}^{+}$to the lumen after luminal $\mathrm{Na}^{+}$removal (Fig. 4, $a$ and $b$ ). A Hanes-Woolf analysis of the data indicates that the Michaelis constant $\left(K_{\mathrm{m}}\right)$ for luminal $\mathrm{Na}^{+}$is $29 \mathrm{mM}$ with a maximum velocity $\left(V_{\max }\right)$ of 0.47 $\mathrm{pH} / \mathrm{min}$.

Plasma membrane $\mathrm{H}^{+}$-ATPase. Additional experiments were performed to determine whether the $S_{3}$ proximal tubule possesses a plasma membrane $\mathrm{H}^{+}$-ATPase and if it has a role in regulating $\mathrm{pH}_{\mathrm{i}}$. In these experiments, the tubules were acutely acidified using the $\mathrm{NH}_{4} \mathrm{Cl}$ prepulse technique (18). $\mathrm{S}_{3}$ tubules were bathed and perfused for $15 \mathrm{~min}$ with $20 \mathrm{mM}$

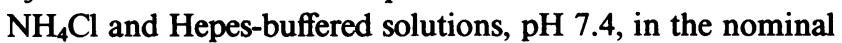
absence of $\mathrm{HCO}_{3}^{-}$, organic anions, and $\mathrm{SO}_{4}{ }^{2-}$. When $\mathrm{NH}_{4} \mathrm{Cl}$ was removed from the lumen and bath (Fig. $5 a$ ), $\mathrm{pH}_{\mathrm{i}}$ fell due to the rapid cellular efflux of $\mathrm{NH}_{3}$ and then recovered at a rate of $0.39 \pm 0.07 \mathrm{pH} / \mathrm{min}(n=6)$. When similar experiments were performed in the absence of luminal and basolateral $\mathrm{Na}^{+}, \mathrm{pH}_{\mathrm{i}}$ recovered at a rate of $0.89 \pm 0.15 \mathrm{pH} / \mathrm{min}(n=11), P<0.05$ (Figs. $5[b]$ and 6). These results indicate the presence of a $\mathrm{Na}^{+}$-independent $\mathrm{pH}_{\mathrm{i}}$ regulatory process in the $\mathrm{S}_{3}$ segment.

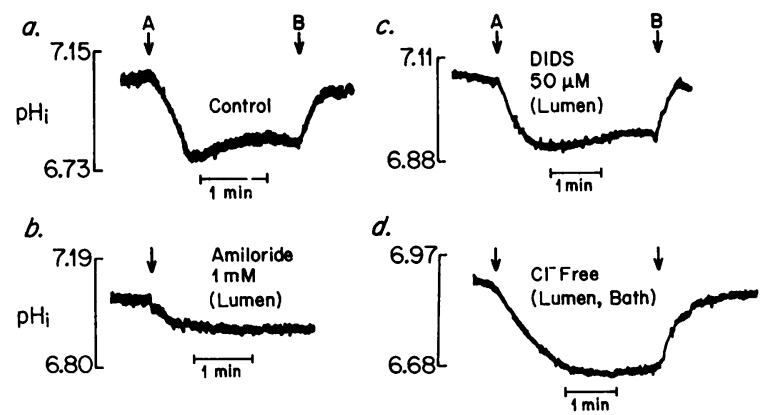

Figure 3. Effect of luminal $\mathrm{Na}^{+}$removal and readdition on $\mathrm{pH}_{\mathrm{i}}$ in $\mathrm{S}_{3}$ tubules. (a) Control: at $A$, luminal $\mathrm{Na}^{+}$was decreased from 140 to 0 $\mathrm{mM}$ resulting in a decrease in $\mathrm{pH}_{\mathrm{i}}$; at $B$, luminal $\mathrm{Na}^{+}$was increased to $140 \mathrm{mM}$, which resulted in the recovery of $\mathrm{pH}_{\mathrm{i}}$. (b) Amiloride $\left(10^{-3} \mathrm{M}\right.$, lumen) significantly decreased change of $\mathrm{pH}_{\mathrm{i}}$ upon luminal $\mathrm{Na}^{+}$removal. $(c, d)$ In the presence of $50 \mu \mathrm{M}$ DIDS (lumen) or $\mathrm{Cl}^{-}$free solutions, the rate of change in $\mathrm{pH}_{\mathrm{i}}$ during the removal, $A$, and readdition of $\mathrm{Na}^{+}, B$, to the lumen was not different from the control rate (See Table I for summary of above results).
Table I. Rate of Decrease in $\mathrm{pH}_{i}$ After Luminal Sodium Removal in $S_{3}$ Tubules

\begin{tabular}{lllll}
\hline & Control & $\begin{array}{l}\text { Amiloride (lumen) } \\
(1 \mathrm{mM})\end{array}$ & $\begin{array}{l}\text { DIDS (lumen) } \\
(50 \mu \mathrm{M})\end{array}$ & $\begin{array}{l}\text { Chloride free } \\
\text { (lumen, bath) }\end{array}$ \\
\hline $\begin{array}{l}\mathrm{dpH}_{\mathrm{i}} / \mathrm{dt}(\mathrm{pH} / \mathrm{min}) \\
n\end{array}$ & $0.34 \pm 0.06$ & $0.13 \pm 0.03^{*}$ & $0.31 \pm 0.04$ & $0.32 \pm 0.05$ \\
6 & 6 & 8 & 4
\end{tabular}

$\mathrm{dpH}_{\mathrm{i}} / \mathrm{dt}$ was measured in the $1 \mathrm{st} 16 \mathrm{~s}$ after removal of luminal $\mathrm{Na}^{+}$. $* P<0.05$ vs. control.

When $S_{2}$ tubules were acidified after a brief exposure to 20 $\mathrm{mM} \mathrm{NH} \mathrm{NCl}_{4}$, like the $\mathrm{S}_{3}$ segment, $\mathrm{pH}_{\mathrm{i}}$ recovered at a rate of $0.55 \pm 0.07 \mathrm{pH} / \mathrm{min}(n=10)$ (Fig. $5 \mathrm{c}$ ). Unlike the $S_{3}$ segment, when $S_{2}$ tubules were acidified in the absence of luminal and basolateral $\mathrm{Na}^{+}$, the $\mathrm{pH}_{\mathrm{i}}$ recovery rate was significantly decreased to $0.10 \pm 0.02 \mathrm{pH} / \mathrm{min}(n=9)$ (Figs. $5[d]$ and 6$), P$ $<0.001$. Therefore, the $\mathrm{Na}^{+}$-independent $\mathrm{pH}_{\mathrm{i}}$ regulatory process is quantitatively greater in the $\mathrm{S}_{3}$ segment.

Further experiments were performed to investigate the $\mathrm{Na}^{+}$-independent $\mathrm{pH}$ regulatory process in $\mathrm{S}_{3}$ tubules. In the presence of $1 \mathrm{mM}$ luminal NEM, a $\mathrm{H}^{+}$-ATPase inhibitor (exposure time, $\sim 15 \mathrm{~min}$ ), the rate of recovery of $\mathrm{pH}_{\mathrm{i}}$ was signifcantly decreased to $0.40 \pm 0.08 \mathrm{pH} / \mathrm{min}(n=7), P<0.02$ (Fig. 7 $a$, Table II). Similarly, $1 \mathrm{mM}$ luminal DCCD, a $\mathrm{H}^{+}$-ATPase inhibitor (exposure time, $\sim 15 \mathrm{~min}$ ), significantly decreased the rate of $\mathrm{pH}_{\mathrm{i}}$ recovery to $0.24 \pm 0.05 \mathrm{pH} / \mathrm{min}(n=9), P$ $<0.01$ (Fig. $7 b$, Table II).

Since the $\mathrm{H}^{+}$-ATPase inhibitors could have altered the recovery of $\mathrm{pH}_{\mathrm{i}}$ by inhibiting mitochondrial oxidative phosphorylation, the $\mathrm{pH}_{\mathrm{i}}$ recovery rate was measured after an

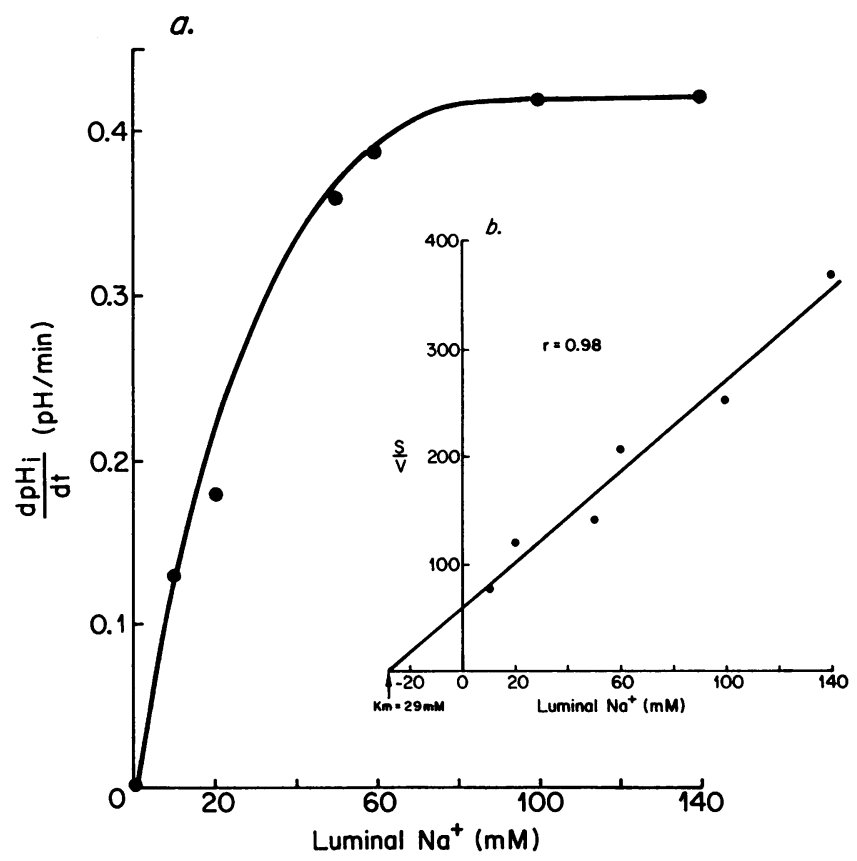

Figure 4. Kinetics of luminal $\mathrm{Na}^{+} / \mathrm{H}^{+}$antiporter. (a) After removal of luminal $\mathrm{Na}^{+}$, varying concentrations of $\mathrm{Na}^{+}(0-140 \mathrm{mM})$ were readded to the lumen and the rate of increase in $\mathrm{pH}_{\mathrm{i}}$ was measured (initial $16 \mathrm{~s}$ ). Each point represents the mean of at least three determinations. (b) A Hanes-Woolf analysis of the data indicates that the $K_{\mathrm{m}}$ is $29 \mathrm{mM}$ for luminal $\mathrm{Na}^{+} ; V_{\max }, 0.47 \mathrm{pH} / \mathrm{min}$. 


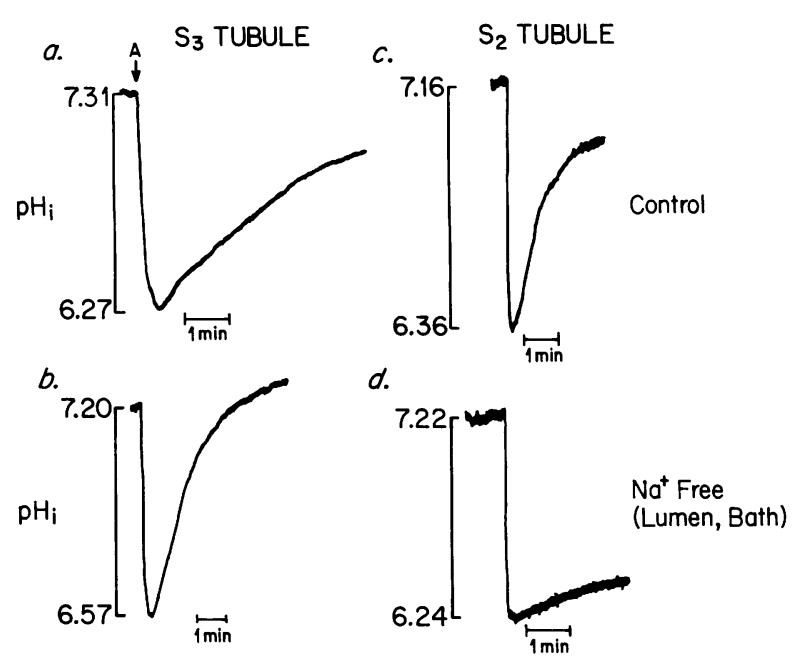

Figure 5. Acute acidification of $\mathrm{pH}_{\mathrm{i}}$ after the removal of $\mathrm{NH}_{4} \mathrm{Cl}$ in $\mathrm{S}_{2}$ and $\mathrm{S}_{3}$ tubules. Tubules were perfused and bathed in $20 \mathrm{mM} \mathrm{NH}_{4} \mathrm{Cl}$ for $15 \mathrm{~min}$. After the removal of $\mathrm{NH}_{4} \mathrm{Cl}$ (lumen, bath) at $A, \mathrm{pH}_{\mathrm{i}}$ decreases due to the rapid cellular efflux of $\mathrm{NH}_{3}$. The decrease in $\mathrm{pH}_{\mathrm{i}}$ is followed by a recovery of $\mathrm{pH}_{\mathrm{i}} . \mathrm{S}_{3}$ tubule: $(a)$ in the presence of 140 $\mathrm{mM} \mathrm{Na}{ }^{+}$(lumen, bath) $\mathrm{pH}_{\mathrm{i}}$ recovered at a rate of $0.39 \pm 0.07 \mathrm{pH} / \mathrm{min}$ $(n=6) ;(b)$ in the absence of $\mathrm{Na}^{+}$(lumen, bath) $\mathrm{pH}_{\mathrm{i}}$ recovered at a rate of $0.89 \pm 0.15 \mathrm{pH} / \mathrm{min}(n=11), P<0.05$. $\mathrm{S}_{2}$ tubule: $(c)$ in the presence of $140 \mathrm{mM} \mathrm{Na}^{+}$(lumen, bath) $\mathrm{pH}_{\mathrm{i}}$ recovered at a rate of $0.55 \pm 0.07 \mathrm{pH} / \mathrm{min}(n=10) ;(d)$ in the absence of $\mathrm{Na}^{+}$(lumen, bath) the $\mathrm{pH}_{\mathrm{i}}$ recovery rate was significantly decreased to $0.10 \pm 0.02 \mathrm{pH} /$ $\min (n=9), P<0.001$.

$\sim$ 30-min exposure of $S_{3}$ tubules to $1 \mathrm{mM}$ potassium cyanide (lumen, bath), an inhibitor of mitochondrial ATP production. The $\mathrm{pH}_{\mathrm{i}}$ recovery rate of $0.69 \pm 0.10 \mathrm{pH} / \mathrm{min}(n=5)$ in the presence of $1 \mathrm{mM} \mathrm{KCN}$ was not significantly different from the control rate (Fig. $8 a$, Table III). These results suggested that if the $\mathrm{Na}^{+}$-independent NEM- and DCCD-sensitive $\mathrm{pH}_{\mathrm{i}}$ regulatory process was a plasma membrane $\mathrm{H}^{+}$-ATPase, the ATP was not being utilized from a mitochondrial source since $1 \mathrm{mM}$ potassium cyanide had no effect on $\mathrm{pH}_{\mathrm{i}}$ regulation.

$H^{+}$-ATPase: source of ATP. Previous studies in turtle urinary bladder (19), Ehrlich ascites cells (20), and rabbit inner stripe medullary collecting tubule cells (21) have demonstrated that the $\mathrm{H}^{+}$-ATPase in these cells can utilize ATP derived from glycolysis. To determine whether the DCCD- and NEM-sensitive $\mathrm{pH}_{\mathrm{i}}$ regulatory process in the $\mathrm{S}_{3}$ tubule can also utilize ATP derived from glycolysis, $S_{3}$ tubules were exposed to the glycolytic inhibitor iodoacetic acid for $\sim 30 \mathrm{~min}$ (lumen and bath). After exposure to $0.5 \mathrm{mM}$ iodoacetic acid, the rate of

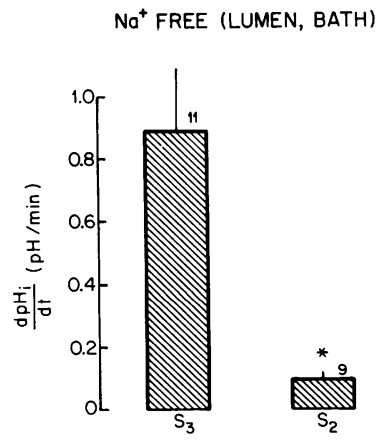

Figure 6. Rate of recovery of $\mathrm{pH}_{\mathrm{i}}$ in $\mathrm{S}_{2}$ and $\mathrm{S}_{3}$ tubules after acidification with $\mathrm{NH}_{4} \mathrm{Cl}$ prepulse in the absence of $\mathrm{Na}^{+}$ (lumen, bath). The recovery rate of $0.10 \pm 0.02 \mathrm{pH} / \mathrm{min}(n$ $=9$ ) in $S_{2}$ tubules was significantly lower than that of $0.89 \pm 0.15 \mathrm{pH} / \mathrm{min}(n=11) \mathrm{S}_{3}$ tubules. $* P<0.001$.

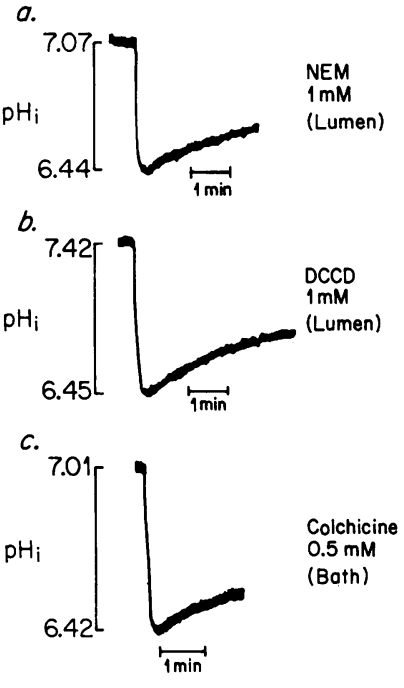

Figure 7. Recovery of $\mathrm{pH}_{\mathrm{i}}$ after intracellular acidification in $\mathrm{S}_{3}$ tubules in the absence of $\mathrm{Na}^{+}$: $\mathrm{H}^{+}$pump inhibition. (a) NEM, $1 \mathrm{mM}$ (lumen). $\mathrm{pH}_{\mathrm{i}}$ recovery rate significantly decreased from $0.89 \pm 0.15(n=11)$ to $0.40 \pm 0.08$ $\mathrm{pH} / \min (n=7), P<0.02$. (b) DCCD, $1 \mathrm{mM}$ (lumen). $\mathrm{pH}_{\mathrm{i}}$ recovery rate significantly decreased to $0.24 \pm 0.05 \mathrm{pH} / \mathrm{min}(n$ $=9), P<0.01$. (c) Colchicine, $0.5 \mathrm{mM}$ (bath). $\mathrm{pH}_{\mathrm{i}}$ recovery rate significantly decreased to $0.20 \pm 0.04 \mathrm{pH} / \mathrm{min}(n=8), P$ $<0.001$.

$\mathrm{pH}_{\mathrm{i}}$ recovery was significantly decreased to $0.12 \pm 0.04 \mathrm{pH} / \mathrm{min}$ $(n=8), P<0.01$ (Fig. $8 b$, Table III).

Exogenous ATP and AMP have recently been reported to increase the ATP content of proximal tubule suspensions via cellular uptake of adenosine, which is converted by adenosine kinase to AMP (22). When $S_{3}$ tubules were exposed to $0.5 \mathrm{mM}$ iodoacetic acid in the presence of $0.25 \mathrm{mM}$ ATP or $0.25 \mathrm{mM}$ AMP (lumen, bath), for $\sim 30 \mathrm{~min}$, the $\mathrm{pH}_{\mathrm{i}}$ recovery rate was normalized (Fig. 8, $c$ and $d$, Table III). In the presence of $1 \mathrm{mM}$ KCN (lumen, bath) and $0.5 \mathrm{mM}$ iodoacetic acid (lumen, bath), $0.25 \mathrm{mM}$ AMP failed to normalize the $\mathrm{pH}_{\mathrm{i}}$ recovery rate (Fig. $8 e$, Table III). In $\mathrm{S}_{3}$ tubules exposed to $0.5 \mathrm{mM}$ iodoacetic acid (lumen, bath) and $0.25 \mathrm{mM}$ GTP (lumen, bath), the $\mathrm{pH}_{\mathrm{i}}$ recovery rate significantly decreased to $0.31 \pm 0.08 \mathrm{pH} / \mathrm{min}$ $(n=4), P<0.05$ (Fig. $8 f$, Table III). These experiments suggest that the $S_{3}$ proximal straight tubule possesses a plasma membrane $\mathrm{H}^{+}$-ATPase that utilizes ATP derived primarily from glycolysis.

$H^{+}$-ATPase: fusion with plasma membrane. In a recent study, Schwartz et al. demonstrated that acidic endocytotic vesicles, possibly containing $\mathrm{H}^{+}$pumps, fused with the apical membrane of the proximal straight tubule when $\mathrm{pH}_{\mathrm{i}}$ was decreased acutely on exposure to $\mathrm{CO}_{2}$ in the presence or absence of $\mathrm{Na}^{+}(8)$. The role of proton pump fusion in $\mathrm{pH}_{\mathrm{i}}$ regulation was therefore investigated in $\mathrm{S}_{3}$ tubules exposed to $0.5 \mathrm{mM}$ colchicine (bath), an inhibitor of microtubule function, for

Table II. Recovery of $\mathrm{pH}_{i}$ After Intracellular Acidification in $\mathrm{S}_{3}$ Tubules in the Absence of Sodium: $\mathrm{H}^{+}$Pump Inhibition

\begin{tabular}{lllll}
\hline & Control & $\begin{array}{l}\text { NEM } \\
(1 \mathrm{mM})\end{array}$ & $\begin{array}{l}\text { DCCD } \\
(1 \mathrm{mM})\end{array}$ & $\begin{array}{l}\text { Colchicine } \\
(0.5 \mathrm{mM})\end{array}$ \\
\hline $\mathrm{dpH}_{\mathrm{i}} / \mathrm{dt}(p H /$ min $)$ & $0.89 \pm 0.15$ & $0.40 \pm 0.08^{*}$ & $0.24 \pm 0.05^{\ddagger}$ & $0.20 \pm 0.04^{8}$ \\
${\mathrm{Minimum} \mathrm{pH}_{\mathrm{i}}}_{n}$ & $6.42 \pm 0.06$ & $6.38 \pm 0.06$ & $6.53 \pm 0.06$ & $6.52 \pm 0.06$ \\
& 11 & 7 & 9 & 8
\end{tabular}

DCCD and NEM were present in the lumen for $\sim 15 \mathrm{~min}$ before performing a study.

Colchicine was present in the bath for $\sim 15$ min before performing a study. $\mathrm{dpH}_{\mathrm{i}} / \mathrm{dt}$ was measured in the initial $16 \mathrm{~s}$ of $\mathrm{pH}_{\mathrm{i}}$ recovery.

$* P<0.02$ vs. control.

$\ddagger P<0.01$ vs. control.

${ }^{5} P<0.001$ vs. control. 


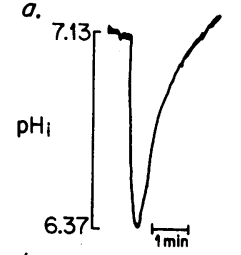

b.
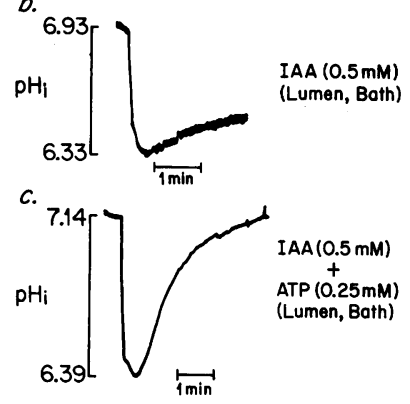

IAA (0.5 mM)
(Lumen, Both)

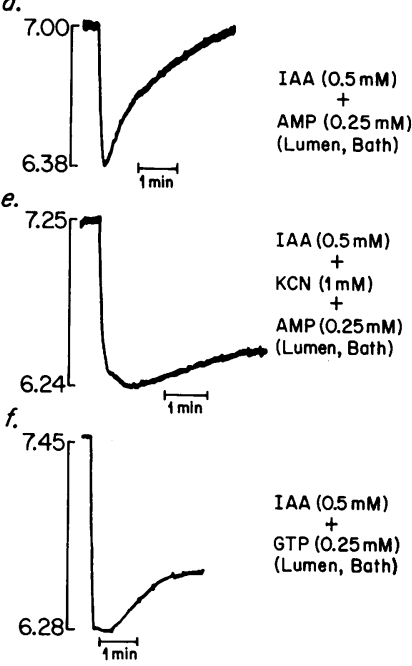

Figure 8. Recovery of $\mathrm{pH}_{\mathrm{i}}$ after intracellular acidification in $\mathrm{S}_{3}$ tubules in the absence of $\mathrm{Na}^{+}$: metabolic inhibition. (a) KCN, $1 \mathrm{mM}$ (lumen, bath). $\mathrm{pH}_{\mathrm{i}}$ recovery rate was $0.69 \pm 0.10 \mathrm{pH} / \mathrm{min}(n=5)$, which was not significantly different from that of the control. (b) Iodoacetic acid, $0.5 \mathrm{mM}$ (lumen, bath). $\mathrm{pH}_{\mathrm{i}}$ recovery rate was significantly decreased to $0.12 \pm 0.04 \mathrm{pH} / \mathrm{min}(n=8), P<0.01$. (c) Iodoacetic acid, $0.5 \mathrm{mM}$ plus ATP, $0.25 \mathrm{mM}$ (lumen, bath). $\mathrm{pH}_{\mathrm{i}}$ recovery rate was $0.69 \pm 0.10 \mathrm{pH} / \mathrm{min}(n=9)$, which was not significantly different from that of the control. $(d)$ Iodoacetic acid, $0.5 \mathrm{mM}$ plus AMP, $0.25 \mathrm{mM}$ (lumen, bath). $\mathrm{pH}_{\mathrm{i}}$ recovery rate was $1.13 \pm 0.17 \mathrm{pH} /$ $\min (n=7)$, which was not significantly different from that of the control. (e) Iodoacetic acid, $0.5 \mathrm{mM}$ plus $\mathrm{KCN}, 1 \mathrm{mM}$ plus AMP, $0.25 \mathrm{mM}$ (lumen, bath). $\mathrm{pH}_{\mathrm{i}}$ recovery rate was significantly decreased to $0.11 \pm 0.05 \mathrm{pH} / \mathrm{min}(n=4), P<0.02$. ( $f)$ Iodoacetic acid, $0.5 \mathrm{mM}$ plus GTP, $0.25 \mathrm{mM}$ (lumen, bath). $\mathrm{pH}_{\mathrm{i}}$ recovery rate was significantly decreased to $0.31 \pm 0.08 \mathrm{pH} / \mathrm{min}(n=4), P<0.05$.

$\sim 15 \mathrm{~min}$ in the nominal absence of $\mathrm{Na}^{+}, \mathrm{HCO}_{3}^{-}$, organic anions, and $\mathrm{SO}_{4}{ }^{2-}$. The $\mathrm{pH}_{\mathrm{i}}$ recovery rate after acidification was significantly decreased to $0.20 \pm 0.04 \mathrm{pH} / \mathrm{min}(n=8), P$ $<0.001$ (Fig. $7 c$, Table II). These results complement those of Schwartz and suggest that in $\mathrm{S}_{3}$ tubules, after intracellular acidification, exocytosis of vesicles containing $\mathrm{H}^{+}$pumps contributes to the recovery of $\mathrm{pH}_{\mathrm{i}}$.

$\mathrm{H}^{+}$-ATPase: $\mathrm{Cl}^{-}$dependence. Further experiments were performed to determine the $\mathrm{Cl}^{-}$dependance of the $\mathrm{H}^{+}$-ATPase and the sidedness of the process. $S_{3}$ tubules were, as in the previous experiments, perfused and bathed in Hepes-buffered

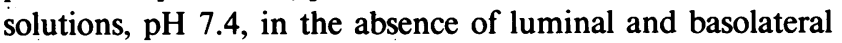
$\mathrm{Na}^{+}$, organic anions, and sulphate. When chloride was removed from the lumen and bath solutions just as the tubule was acidified, (by removal of $\mathrm{NH}_{4} \mathrm{Cl}$ ) the $\mathrm{pH}_{\mathrm{i}}$ recovery rate was not different than the control rate (Fig. $9 a$ ). This result indicates that extracellular chloride is not required for $\mathrm{pH}_{\mathrm{i}}$ recovery. When $\mathrm{S}_{3}$ tubules were perfused and bathed in a $\mathrm{Cl}^{-}$-free solution for $30 \mathrm{~min}$ to decrease the intracellular chloride concentration and then acidified by removal of $20 \mathrm{mM}$ ammonium gluconate, $\mathrm{pH}_{\mathrm{i}}$ failed to recover normally (Fig. $9 \mathrm{~b}$ ). These results suggest that intracellular rather than extracellular chloride is required for $\mathrm{pH}_{\mathbf{i}}$ recovery. Intracellular $\mathrm{Cl}^{-}$may have been required both for the $\mathrm{H}^{+}$-ATPase and for a plasma membrane $\mathrm{Cl}^{-}$-base exchanger. However, $50 \mu \mathrm{M}$ DIDS in the lumen and bath did not affect the $\mathrm{pH}_{\mathrm{i}}$ recovery rate (Fig. $9 c$ ), which suggests that reversal of a plasma membrane $\mathrm{Cl}^{-}$-base

exchanger was not contributing significantly to the recovery of $\mathrm{pH}_{\mathrm{i}}$ (Fig. $\left.9 c\right)^{3}$

\section{Discussion}

Fluorescent measurement of $p H_{i}$. In this study, new fluorescent methodology was developed to measure $\mathrm{pH}_{\mathrm{i}}$ in the isolated perfused renal tubule preparation. Several techniques are currently available for measuring $\mathrm{pH}_{\mathrm{i}}$ in living cells (18). Of the several methods available, optical techniques have a number of important advantages, notably, rapid response time, excellent pH sensitivity, and a high signal-to-noise ratio. Despite these advantages, several difficulties are encountered when monitoring $\mathrm{pH}_{\mathrm{i}}$ in cells with optical probes, which include ( $i$ ) dye leakage (active, passive), (ii) bleaching, and (iii) photodynamic damage (24). The fluorescent $\mathrm{pH}$ probe, BCECF (16), has a maximum in its excitation spectrum at $\sim 500 \mathrm{~nm}$ and an isosbestic wavelength at $\sim 440 \mathrm{~nm}$; therefore, the ratio of the 500 to $440 \mathrm{~nm}$ excitation intensities (emission $530 \mathrm{~nm}$ ) will be independent of dye leakage and bleaching artifacts. In previous studies using BCECF, excitation wavelength switching has been achieved with either filter wheel rotation, motorized monochrometers, or manual sliding of interference filters in front of the excitation source. These methodologies are limited in that the two excitation intensities are not determined simultaneously. Therefore a new technique was developed in the present study to excite the tubule cells at 440 and $500 \mathrm{~nm}$ simultaneously. By modulating the 440 and $500 \mathrm{~nm}$ fluorescent excitation intensities at two separate frequencies, the two excitation intensities could be measured simultaneously by using two lock-in amplifiers to demodulate the 530-nm fluorescence emission into the 440- and 500 -nm components. By measuring the $500 / 440 \mathrm{~nm}$ excitation ratio simultaneously, the inaccuracy in the measurement due to dye loss and bleaching artifacts was minimized, and rapid changes in the fluorescent excitation ratio could be monitored in real time.

Apical $\mathrm{Na}^{+} / \mathrm{H}^{+}$exchanger. In $\mathrm{S}_{3}$ tubules, steady state $\mathrm{pH}_{\mathrm{i}}$

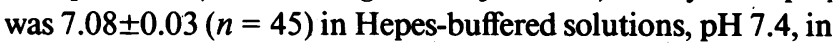
the absence of organic anions and sulphate. This value is similar to that reported in the rat proximal convoluted tubule (5, 25 ) and the rabbit $S_{2}$ proximal straight tubule (4) in $\mathrm{HCO}_{3}^{-}$buffered media. The results of the present study provide direct evidence for an apical $\mathrm{Na}^{+} / \mathrm{H}^{+}$antiporter in rabbit $\mathrm{S}_{3}$ tubules as has previously been demonstrated in the rabbit and rat proximal convoluted tubule $(2,5)$, the rabbit $S_{2}$ proximal straight tubule (4), and the salamander proximal tubule (3). The antiporter was shown to play an important role in $\mathrm{pH}_{\mathbf{i}}$ regulation in the $\mathrm{S}_{3}$ segment. Kinetic studies revealed a $K_{\mathrm{m}}$ of

3. These results do not rule out the presence of a $\mathrm{Cl}^{-}$-base exchanger in the $\mathrm{S}_{3}$ segment. These findings suggest, however, that if a $\mathrm{Cl}^{-}$-base exchanger is present under the conditions of this study, this transporter does not contribute to the recovery of $\mathrm{pH}_{\mathrm{i}}$ after an acute intracellular acid load as recently described in Madin-Darby cannine kidney cells (23). Also, since these experiments were performed in the nominal absence of $\mathrm{HCO}_{3}^{-}$, the rate of $\mathrm{Cl}^{-}$-base exchange is likely decreased (23).

4. The kinetics of $\mathrm{Na}^{+}$-dependent recovery of $\mathrm{pH}_{\mathrm{i}}$ could have been affected by the paracellular backleak of $\mathrm{Na}^{+}$from bath to lumen. Assuming a transepithelial $\mathrm{Na}^{+}$permeability of $6 \times 10^{-5} \mathrm{~cm} / \mathrm{s}(26)$ and a tubule radius of $10 \mu \mathrm{m}$, a backflux of $300 \mathrm{pmol} / \mathrm{mm}$ per min would be expected. Since the length of the tubules studied was $0.7 \mathrm{~mm}$, with a 
Table III. Recovery of $\mathrm{pH}_{i}$ After Intracellular Acidification in $S_{3}$ Tubules in the Absence of Sodium: Metabolic Inhibition

\begin{tabular}{|c|c|c|c|c|c|c|c|}
\hline & Control & $\begin{array}{l}\mathrm{KCN} \\
(1 \mathrm{mM})\end{array}$ & $\begin{array}{l}\text { Iodacetic acid } \\
(0.5 \mathrm{mM})\end{array}$ & $\begin{array}{l}\text { Iodacetic acid } \\
(0.5 \mathrm{mM})+\text { AMP } \\
(0.25 \mathrm{mM})\end{array}$ & $\begin{array}{l}\text { Iodacetic acid } \\
(0.5 \mathrm{mM})+\text { ATP } \\
(0.25 \mathrm{mM})\end{array}$ & $\begin{array}{l}\text { Iodacetic acid } \\
(0.5 \mathrm{mM})+\mathrm{KCN} \\
(1 \mathrm{mM})+\mathrm{AMP} \\
(0.25 \mathrm{mM})\end{array}$ & $\begin{array}{l}\text { Iodacetic acid } \\
(0.5 \mathrm{mM})+\text { GTP } \\
(0.25 \mathrm{mM})\end{array}$ \\
\hline $\mathrm{dpH}_{\mathrm{i}} / \mathrm{dt}(p H / \min )$ & $0.89 \pm 0.15$ & $0.69 \pm 0.10$ & $0.12 \pm 0.04^{*}$ & $1.13 \pm 0.17$ & $0.69 \pm 0.10$ & $0.11 \pm 0.05^{\ddagger}$ & $0.31 \pm 0.08^{\S}$ \\
\hline Minimum $\mathrm{pH}_{\mathrm{i}}$ & $6.42 \pm 0.06$ & $6.42 \pm 0.03$ & $6.43 \pm 0.06$ & $6.41 \pm 0.08$ & $6.36 \pm 0.04$ & $6.20 \pm 0.04$ & $6.42 \pm 0.07$ \\
\hline$n$ & 11 & 5 & 8 & 7 & 9 & 4 & 4 \\
\hline
\end{tabular}

All compounds were present in the lumen and bath for $\sim 30 \min$ before performing a study. $\mathrm{dpH}_{\mathrm{i}} / \mathrm{dt}$ was measured in the initial $16 \mathrm{~s}$ of $\mathrm{pH}_{\mathrm{i}}$ recovery. ${ }^{*} P<0.01$ vs. control. ${ }^{\ddagger} P<0.02$ vs. control. ${ }^{\S} P<0.05$ vs. control.

$29 \mathrm{mM}$ for luminal $\mathrm{Na}^{+}$and a $V_{\max }$ of $0.47 \mathrm{pH} / \mathrm{min} .^{4}$ The $K_{\mathrm{m}}$ of $29 \mathrm{mM}$ is almost identical to the value of $27.3 \mathrm{mM}$ recently reported by Chaillet et al. for the $\mathrm{Na}^{+} / \mathrm{H}^{+}$antiporter in the basolateral membrane of the rabbit cortical collecting duct (28). The $V_{\max }$ of $0.47 \mathrm{pH} / \mathrm{min}$ in the $\mathrm{S}_{3}$ segment is lower than previously reported in the cortical collecting tubule (28) and may reflect either a lower number of antiporters or a decreased rate of ion transport per antiporter in the $S_{3}$ segment. In a recent study, Kragh-Hansen et al. using the rapid filtration technique failed to find evidence for a $\mathrm{Na}^{+} / \mathrm{H}^{+}$exchanger in brush border vesicles isolated from rabbit outer medulla (29). However, in a more recent study, antiport activity was demonstrated using acridine orange (27). The reason for the lack of demonstrable $\mathrm{Na}^{+} / \mathrm{H}^{+}$antiport activity in the initial study is not clear, but may be due to the lower $V_{\max }$ of the antiporter in the $\mathrm{S}_{3}$ segment. Recent studies indicate that the $V_{\max }$ of the antiporter in the $S_{2}$ segment is three to four times the value in the $S_{3}$ segment (27, Kurtz, I., unpublished results). These kinetic differences possibly account for the low $\mathrm{HCO}_{3}^{-}$absorptive rate in the $S_{3}$ segment $(<8 \mathrm{pmol} / \mathrm{min}$ per $\mathrm{mm})$ as compared with the $\mathrm{S}_{2}$ tubule (13).

Plasma membrane $H^{+}$-ATPase. In the $\mathrm{S}_{3}$ tubule after acute intracellular acidification, $\mathrm{pH}_{\mathrm{i}}$ recovered more rapidly in the absence of luminal and basolateral sodium than in the presence of $\mathrm{Na}^{+}$. This finding suggests that either $(a) \mathrm{a} \mathrm{Na}^{+}$-dependent base efflux pathway such as a basolateral $\mathrm{Na}^{+}$-base cotransporter diminished the rate of recovery of $\mathrm{pH}_{\mathrm{i}}$ in the presence of $\mathrm{Na}^{+}$, or $(b)$ the rate of the $\mathrm{Na}^{+}$-independent $\mathrm{pH}_{\mathrm{i}}$ regulatory process is diminished in the presence of $\mathrm{Na}^{+}$. The results of the present study do not distinguish between these possibilities. In the rat proximal tubule a $\mathrm{Na}^{+}$-independent DCCD-sensitive transport process accounts for $\sim 15 \%$ of luminal $\mathrm{HCO}_{3}^{-}$absorption (9). The $\mathrm{Na}^{+}$-independent $\mathrm{pH}_{\mathrm{i}}$ recovery rate in the $S_{3}$ tubule was also DCCD sensitive in addition to being NEM sensitive, but was not affected by inhibition of mitochondrial oxidative phosphorylation with $\mathrm{KCN}$. Iodoacetic acid, an inhibitor of glycolysis, significantly decreased the $\mathrm{Na}^{+}$-independent $\mathrm{pH}_{\mathrm{i}}$ recovery rate despite normal functioning mitochondria. When $S_{3}$ tubules were exposed to iodoacetic

perfusion rate of $\sim 50 \mathrm{nl} / \mathrm{min}$ per $\mathrm{mm}$, the mean luminal $\mathrm{Na}^{+}$concentration would be $\sim 2 \mathrm{mM}$ greater than the perfusate $\mathrm{Na}^{+}$concentration. Using the corrected luminal $\mathrm{Na}^{+}$concentration in the kinetic analysis, the $V_{\max }$ for the luminal $\mathrm{Na}^{+}$is $0.49 \mathrm{pH} / \mathrm{min}$ instead of 0.47 $\mathrm{pH} / \mathrm{min}$ and the $K_{\mathrm{m}}$ for luminal $\mathrm{Na}^{+}$is $34 \mathrm{mM}$ instead of $29 \mathrm{mM}$. The $K_{\mathrm{m}}$ of $29 \mathrm{mM}$ and the corrected value of $34 \mathrm{mM}$ for luminal $\mathrm{Na}^{+}$ bracket the $K_{\mathrm{m}}$ of $32 \mathrm{mM}$ recently determined for $\mathrm{Na}^{+}$in outer medullary brush border vesicles (27). acid in addition to either AMP or ATP, the $\mathrm{pH}_{\mathrm{i}}$ recovery rate was normalized. GTP, however, failed to normalize the rate of $\mathrm{pH}_{\mathrm{i}}$ recovery. These findings suggest that the $\mathrm{S}_{3}$ tubule possesses a plasma membrane $\mathrm{H}^{+}$-ATPase that utilizes ATP derived primarily from glycolysis. The mechanism by which this occurs is unknown, but may involve the physical proximity of membrane-bound glycolytic enzymes and the transport proteins as postulated in erythrocytes, vascular smooth muscle, and cultured cells (30-32). It is also possible that the quantity of ATP produced from glycolysis is greater than mitochondrial ATP production rate in the $S_{3}$ segment. The utilization of ATP derived from glycolysis by a transport process in the proximal tubule is surprising given the current dogma that the rate of glycolysis in this part of the nephron is low. A recent preliminary report, however, suggests that the rate of glycolysis in the rabbit proximal straight tubule is greater than that in the proximal convoluted segment (33).

When glycolysis was inhibited with iodoacetic acid, exogenous AMP or ATP normalized the $\mathrm{pH}_{\mathrm{i}}$ recovery rate. Recent studies have demonstrated that exogenous adenosine nucleotides increase the cytoplasmic ATP concentration in proximal tubule suspensions via cellular uptake of adenosine, which is converted to AMP by adenosine kinase. The sidedness of the process was not examined in the present study as the nucleotides were added to both the luminal and bathing solutions. The finding in the present study that $1 \mathrm{mM} \mathrm{KCN}$ prevented exogenous AMP from normalizing $\mathrm{pH}_{\mathrm{i}}$ in the presence of iodoacetic acid suggests that functional mitochondria were required for exogenous AMP to normalize the $\mathrm{pH}_{\mathrm{i}}$ recovery rate when glycolysis was inhibited. Therefore, ATP derived from a mitochondrial source under certain circumstances can be uti-

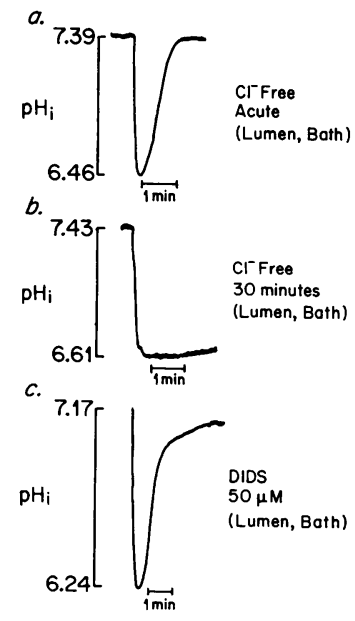

Figure 9. (a) $\mathrm{Cl}^{-}$was removed from the bath and lumen immediately after acidification of $\mathrm{pH}_{\mathrm{i}}$ by $\mathrm{NH}_{4} \mathrm{Cl}$ removal. Acute $\mathrm{Cl}^{-}$removal failed to inhibit the recovery of $\mathrm{pH}_{\mathrm{i}}$. (b) $\mathrm{Cl}^{-}$ was removed from bath and lumen for $30 \mathrm{~min}$ to decrease the intracellular $\mathrm{Cl}^{-}$before acidification of $\mathrm{pH}_{\mathrm{i}}$ by ammonium gluconate removal. After chronic $\mathrm{Cl}^{-}$removal, $\mathrm{pH}_{\mathrm{i}}$ failed to recover normally. (c) Recovery of $\mathrm{pH}_{\mathrm{i}}$ in the presence of $50 \mu \mathrm{M}$ DIDS (lumen, bath). $50 \mu \mathrm{M}$ DIDS failed to inhibit the recovery of $\mathrm{pH}_{\mathrm{i}}$. All experiments in $(a-c)$ were performed in the absence of $\mathrm{Na}^{+}$(lumen, bath). 
lized by the proton pump, which indicates that the coupling to glycolysis is not obligatory.

In contrast to the proton pump utilizing ATP derived primarily from glycolysis in the $\mathrm{S}_{3}$ tubule, $\mathrm{Na}^{+}$efflux by the basolateral $\mathrm{Na}^{+}-\mathrm{K}^{+}-\mathrm{ATPase}$ in the proximal tubule is coupled to mitochondrial oxidative phosphorylation (34). The rate of $\mathrm{Na}^{+}$-coupled transport is greatest in the earliest portion of the proximal tubule $\left(S_{1}\right.$ segment) and decreases along the length of the proximal tubule (35) as does the number of mitochondria. In the $S_{1}$ segment of the proximal tubule, which has the highest rate of fluid and $\mathrm{HCO}_{3}^{-}$absorption, the mitochondria are large, numerous, and arranged perpendicularly near the basolateral cell membrane (36). In the $S_{3}$ segment, which has the lowest rate of fluid and $\mathrm{HCO}_{3}^{-}$absorption (13), mitochondria are few in number and are scattered throughout the cytoplasm (36).

Recent studies by Schwartz et al. have demonstrated that acidic endocytotic vesicles fuse with the apical membrane of $\mathrm{S}_{2}$ proximal straight tubules when exposed to $\mathrm{CO}_{2}(8)$. These vesicles were presumed to contain $\mathrm{H}^{+}$pumps that fused with the apical membrane during acute cytoplasmic acidification. Colchicine inhibited the fusion process. In the present study, colchicine was also found to impair the $\mathrm{Na}^{+}$-independent $\mathrm{pH}_{\mathrm{i}}$ recovery rate in $\mathrm{S}_{3}$ tubules, which suggests that fusion of cytoplasmic vesicles containing $\mathrm{H}^{+}$pumps occurred in response to acute acidification of $\mathrm{pH}_{\mathrm{i}}$. In the present study, unlike the $\mathrm{S}_{3}$ segment, $\mathrm{S}_{2}$ tubules failed to recover $\mathrm{pH}_{\mathrm{i}}$ normally in the absence of luminal and basolateral $\mathrm{Na}^{+}$. Although these results do not rule out a $\mathrm{pH}_{\mathrm{i}}$ regulatory role for a plasma membrane $\mathrm{H}^{+}$pump in the $\mathrm{S}_{2}$ segment, the role of the $\mathrm{H}^{+}$pump in regulating $\mathrm{pH}_{\mathrm{i}}$ appears to be quantitatively greater in the $\mathrm{S}_{3}$ segment. Whether the difference is due to a greater number of copies of plasma membrane $\mathrm{H}^{+}$-ATPase in the $\mathrm{S}_{3}$ segment, a greater flux of protons per ATPase, or simply a greater number of fusion events is not presently known. The results of the present study complement the study of Abdelkhalek et al. (12), which localized extramitochondrial microsomal $\mathrm{HCO}_{3}^{-}$-ATPase along the rabbit nephron. In that study, the highest enzyme activity was found in the $S_{3}$ proximal straight tubule and the late distal convoluted tubule. Whether this enzyme is the same enzyme involved in $\mathrm{H}^{+}$transport or $\mathrm{pH}_{\mathrm{i}}$ regulation remains to be determined.

Recent studies have documented the requirement of the renal $\mathrm{H}^{+}$-ATPase for chloride $(10,11,37)$. Chloride, in addition to providing a conductance for the electrogenic $\mathrm{H}^{+}$pump, appears to activate the pump at a separate regulatory site. In a recent study, $\mathrm{Cl}^{-}$stimulated proton pump transport in a dosedependent manner with a $\mathrm{K}_{0.5}$ of $7 \mathrm{mM}$ (11) for chloride. The results of the present study also document the requirement of the $\mathrm{H}^{+}$pump for intracellular chloride since the $\mathrm{Na}^{+}$-independent $\mathrm{pH}_{\mathrm{i}}$ recovery rate was significantly decreased in $\mathrm{S}_{3}$ tubules depleted of intracellular chloride.

In summary, $S_{3}$ proximal tubules possess an apical $\mathrm{Na}^{+} / \mathrm{H}^{+}$ antiporter with a $K_{\mathrm{m}}$ of $29 \mathrm{mM}$ for luminal $\mathrm{Na}^{+}$and a $V_{\max }$ of $0.47 \mathrm{pH} / \mathrm{min} . \mathrm{S}_{3}$ tubules also possess a plasma membrane $\mathrm{H}^{+}$ATPase that can regulate $\mathrm{pH}_{i}$, has a requirement for intracellular chloride, and utilizes ATP derived primarily from glycolysis.

\section{Acknowledgments}

This research was supported by the following grants: R23AM36324 from the National Institutes of Health-USPHS and W860521 from the National Kidney Foundation of Southern California.

\section{References}

1. Mahnensmith, R. L., and P. S. Aronson. 1985. The plasma membrane sodium-hydrogen exchanger and its role in physiological and pathophysiological processes. Circ. Res. 56:778-788.

2. Schwartz, G. J. 1981. $\mathrm{Na}^{+}$-dependent $\mathrm{H}^{+}$efflux from proximal tubule: evidence for reversible $\mathrm{Na}^{+}-\mathrm{H}^{+}$exchange. Am. J. Physiol. 241 (Renal Fluid Electrolyte Physiol. 10):F380-F385.

3. Boron, W. F., and E. L. Boulpaep. 1983. Intracellular pH regulation in the renal proximal tubule of the salamander: $\mathrm{Na}-\mathrm{H}$ exchange. $J$. Gen. Physiol. 81:29-52.

4. Sasaki, S., T. Shiigai, and J. Takeuchi. 1985. Intracellular pH in the isolated perfused rabbit proximal tubule. Am. J. Physiol. 249 (Renal Fluid Electrolyte Physiol. 18):F417-F423.

5. Alpern, R. J., and M. Chambers. 1986. Cell pH in the rat proximal convoluted tubule. Regulation by luminal and peritubular $\mathrm{pH}$ and sodium concentration. J. Clin. Invest. 78:502-510.

6. Kinne-Saffran, E., R. Beauwens, and R. Kinne. 1982. An ATP driven proton pump in brush border membranes from rat renal cortex. J. Membr. Biol. 64:67-76.

7. Bichara, M., M. Paillard, F. Leviel, A. Prigent, and J. P. Gordin. 1983. $\mathrm{Na}^{+}-\mathrm{H}^{+}$exchange and the primary $\mathrm{H}^{+}$pump in the proximal tubule. Am. J. Physiol. 244 (Renal Fluid Electrolyte Physiol. 13):F165-F171.

8. Schwartz, G. J., and Q. Al-Awqati. 1985. Carbon dioxide causes exocytosis of vesicles containing $\mathrm{H}^{+}$pumps in isolated perfused proximal and collecting tubules. J. Clin. Invest. 75:1,638-1,644.

9. Bank, N., H. S. Aynedjian, and B. F. Mutz. 1985. Evidence for DCCD-sensitive component of proximal bicarbonate reabsorption. Am. J. Physiol. 249 (Renal Fluid Electrolyte Physiol. 18):F636-F644.

10. Sabolic, I., and G. Burckhardt. Characteristics of the proton pump in rat renal cortical endocytotic vesicles. Am. J. Physiol. 250 (Renal Fluid Electrolyte Physiol. 19):F817-F826.

11. Ait-Mohamed, A. K., S. Marsy, C. Barlet, C. Khadouri, and A. Doucet. 1986. Characterization of $\mathrm{N}$-ethylmaleimide-sensitive proton pump in the rat kidney: localization along the nephron. J. Biol. Chem. 261:12,526-12,533.

12. Abdelkhalek, M. B., C. Barlet, and A. Doucet. 1986. Presence of an extramitochondrial anion-stimulated ATPase in the rabbit kidney: localization along the nephron and effect of corticosteroids. $J$. Membr. Biol. 89:225-240.

13. Kurtz, I., R. Star, R. S. Balaban, J. L. Garvin, and M. A. Knepper. 1986. Spontaneous luminal disequilibrium pH in S3 proximal tubules. Role in ammonia and bicarbonate transport. J. Clin. Invest. 78:989-996.

14. Burg, M. B. 1972. Perfusion of isolated renal tubules. Yale J. Biol. Med. 45:321-326.

15. Rink, T. J., R. Y. Tsien, and T. Pozzan. 1982. Cytoplasmic pH and free $\mathrm{Mg}^{++}$in lymphocytes. J. Cell Biol. 95:189-196.

16. Spray, D. C., J. Nerbonne, A. Campos de Carvalho, A. L. Harris, and M. V. L. Bennett. 1984. Substituted benzyl acetates: a new class of compounds that reduce gap functional conductance by cytoplasmic acidification. J. Cell Biol. 99:174-179.

17. Chaillet, J. R., and W. F. Boron. 1985. Intracellular calibration of a pH-sensitive dye in isolated, perfused salamander proximal tubules. J. Gen. Physiol. 86:765-794.

18. Roos, A., and W. F. Boron. 1981. Intracellular pH. Physiol. Rev. 61:297-434.

19. Schwartz, J. H., and P. R. Steinmetz. 1977. Metabolic energy and $\mathrm{PCO}_{2}$ as determinants of $\mathrm{H}^{+}$secretion by turtle urinary bladder. Am. J. Physiol. 233:F145-F149.

20. Heinz, A., G. Sachs, and J. A. Schafer. 1981. Evidence for activation of an active electrogenic proton pump in Ehrlich acites tumor cells during glycolysis. J. Membr. Biol. 61:143-153.

21. Zeidel, M. L., P. Silva, and J. L. Seifter. 1986. Intracellular pH regulation and proton transport by rabbit renal medullary collecting duct cells. Role of membrane proton adenosine triphosphate. J. Clin. Invest. 77:113-120. 
22. Davis, J. A., M. Abarzua, A. Lawton, and J. M. Weinberg. 1987. Increases of tubule cell ATP produced by exogenous adenine nucleotides are entirely mediated by adenosine uptake. Kidney Int. 31:397. (Abstr.)

23. Kurtz, I., and K. Golchini. 1987. $\mathrm{Na}^{+}$-independent $\mathrm{Cl}^{-}-\mathrm{HCO}_{3}^{-}$ exchange in Madin-Darby canine kidney cells: role in intracellular $\mathrm{pH}$ regulation. J. Biol. Chem. 262:4,516-4,520.

24. Kurtz, I., and R. S. Balaban. 1985. Fluorescence emission spectroscopy of 1,4-dihydroxyphthalonitrile. A method for determining intracellular pH in cultured cells. Biophys. J. 48:449-508.

25. Yoshitomi, K., and E. Fromter. 1984. Cell pH of rat renal proximal tubule in vivo and the conductive nature of peritubular $\mathrm{HCO}_{3}-\left(\mathrm{OH}^{-}\right)$exit. Pfluegers Arch. Eur. J. Physiol. 402:300-305.

26. Kawamura, S., M. Imai, D. W. Seldin, and J. P. Kokko. 1975. Characteristics of salt and water transport in superficial and juxtamedullary straight segments of proximal tubules. J. Clin. Invest. 55:1,269-1,277.

27. Jacobsen, C., U. Kragh-Hansen, and M. I. Sheikh. 1986. $\mathrm{Na}^{+}-\mathrm{H}^{+}$exchange in luminal-membrane vesicles from rabbit proximal convoluted and straight tubules in response to metabolic acidosis. Biochem. J. 239:411-416.

28. Chaillet, J. R., A. G. Lopes, and W. F. Boron. 1985. Basolateral Na-H exchange in the rabbit cortical collecting tubule. J. Gen. Physiol. 86:795-812.

29. Kragh-Hansen, U., H. Roigaard-Petersen, and M. I. Sheikh. 1985. Segmental localization of the rabbit renal proximal tubular $\mathrm{Na}^{+}-\mathrm{H}^{+}$exchange system. Am. J. Physiol. 249 (Renal Fluid Electrolyte Physiol. 18):F704-F712.
30. Mercer, R. W., and P. B. Dunham. 1981. Membrane-bound ATP fuels the $\mathrm{Na} / \mathrm{K}$ pump. Studies on membrane-bound glycolytic enzymes on inside-out vesicles from human red cell membranes. $J$. Gen. Physiol. 78:547-568.

31. Paul, R. J., M. Bauer, and W. Pease. 1979. Vascular smooth muscle: aerobic glycolysis linked to sodium and potassium transport processes. Science (Wash. DC). 206:1,414-1,416.

32. Balaban, R. S., and J. P. Bader. 1984. Studies on the relationship between glycolysis and $\left(\mathrm{Na}^{+}-\mathrm{K}^{+}\right)$-ATPase in cultured cells. Biochim. Biophys. Acta. 804:419-426.

33. Yanagawa, N. 1986. Glucose metabolism in isolated perfused rabbit proximal tubules: an optical approach. Kidney Int. 31:404. (Abstr.)

34. Mandel, L. J., and R. S. Balaban. 1981. Stoichiometry and coupling of active transport to oxidative metabolism in epithelial tissues. Am. J. Physiol. 240 (Renal Fluid Electrolyte Physiol. 9):F357F371.

35. Knepper, M., and M. Burg. 1983. Organization of nephron function. Am. J. Physiol. 244 (Renal Fluid Electrolyte Physiol. 13):F579-F589.

36. Kaissling, B., and W. Kriz. 1979. Structural analysis of the rabbit kidney. In Advances in Anatomy, Embryology and Cell Biology. A. Brodal, W. Hild, J. van Limborgh, R. Ortmann, T. H. Schiebler, G. Töndury, and E. Wolff 56th ed. Springer-Verlag New York Inc., New York. 42-51.

37. Kaunitz, J. D., R. D. Gunther, and G. Sachs. 1985. Characterization of an electrogenic ATP and chloride-dependent proton translocating pump from rat renal medulla. J. Biol. Chem. 260:11,56711,573 . 